\title{
Foveal and parafoveal retinal thickness in healthy pregnant women in their last trimester
}

This article was published in the following Dove Press journal:

Clinical Ophthalmology

22 September 2011

Number of times this article has been viewed

\section{Mehmet Demir \\ Ersin Oba \\ Efe Can \\ Mahmut Odabasi \\ Semra Tiryaki \\ Erhan Ozdal \\ Hakan Sensoz}

Eye Clinic, Sisli Etfal Training and Research Hospital, Istanbul, Turkey

Correspondence: Mehmet Demir Hasat Sok, No: 42/6 pk. 34400 Sislı, Istanbul, Turkey

Tel +90 2I2 24I488I

Fax $+9021224|488|$

Email drmehmetfe@hotmail.com
Purpose: The inspection of foveal and parafoveal thickness in healthy pregnant women in the last trimester.

Materials and methods: This study included 40 healthy pregnant women in their last trimester (study group: 40 women, 80 eyes) and 37 nonpregnant women (control group: 37 women, 74 eyes). Visual acuity, intraocular pressure, slit lamp examination of anterior and posterior segments, and visual field examination with automated perimetry were performed in both groups. Foveal and parafoveal thickness in the four quadrants (upper, nasal, temporal, and inferior parafoveal) and peripapillary retinal nerve fiber layer were measured by optical coherence tomography. There were no systemic or ocular problems in either group. Findings were analyzed with statistical software. A $P$ value $<0.05$ was considered statistically significant.

Results: Mean foveal and parafoveal thicknesses in the study group were: foveal $236.12 \pm 27.28 \mu \mathrm{m}$, upper quadrant $321.31 \pm 12.28 \mu \mathrm{m}$, temporal quadrant $307.0 \pm 12.05 \mu \mathrm{m}$, inferior quadrant $317.0 \pm 10.58 \mu \mathrm{m}$, and nasal quadrant $313.62 \pm 14.51 \mu \mathrm{m}$. Mean foveal and parafoveal thicknesses in the control group were: foveal $224.62 \pm 21.19 \mu \mathrm{m}$, upper quadrant $311.62 \pm 12.71 \mu \mathrm{m}$, temporal quadrant $296.87 \pm 13.78 \mu \mathrm{m}$, inferior quadrant $305.43 \pm 13.25 \mu \mathrm{m}$, and nasal quadrant $304.93 \pm 13.44 \mu \mathrm{m}$. Mean retinal nerve fiber layer thicknesses in the study and control group were $110 \pm 12.4 \mu \mathrm{m}$ and $108 \pm 13.1 \mu \mathrm{m}$, respectively.

Conclusion: Mean retinal thickness in pregnant women was higher than control group in all measurements. Statistically significant difference in thickness was only found in upper, temporal, and inferior parafoveal areas.

Keywords: pregnancy, last trimester, foveal and parafoveal thickness, optical coherence tomography

\section{Introduction}

During pregnancy, periodical hormonal, metabolic, hematologic, vascular, and immunological changes can be observed. ${ }^{1}$ Pregnancy hormones may lead to an increase in fluid volume in many tissues of the body. Ocular changes during pregnancy are related to adnexa of eye, anterior and posterior segment, and decreased intraocular pressure. ${ }^{2,3}$ Ocular changes are usually temporary but occasionally permanent. Changes may be associated with development of new ocular conditions or the exacerbation of preexisting conditions, especially diabetic retinopathy. ${ }^{4,5}$ Optical coherence tomography (OCT) is used daily in ophthalmology. With an axial resolution of $4-10 \mu \mathrm{m}$, it is used to investigate the vitreoretinal surface for diagnosis, inspection, or follow-up of treatment processes. The increase of fluid in the body, especially in the last trimester, may cause an increase of retinal thickness. 
This paper investigates foveal and parafoveal retinal thickness in healthy pregnant women in their last trimester.

\section{Materials and methods}

This study included two groups: a study group, which included 40 healthy pregnant women in their last trimester (80 eyes), and a control group, which included 37 healthy nonpregnant women (74 eyes). All participants gave informed consent to the study, and the tenets of the Declaration of Helsinki were followed.

A detailed history was taken in all cases, and visual acuity, intraocular pressure, refractive errors, and peripapillary retinal nerve fiber layer (RNFL) were measured. Visual field test was performed in all participants. Anterior and posterior segment were examined under slit lamp (SL-8, Topcon Medical Systems, Inc, Tokyo, Japan). Inclusion criteria for the study group were: healthy pregnant women in their last trimester; visual acuity $0.00 \log \mathrm{MAR}$ without correction; no refractive errors higher than -0.50 or $+0.50 \mathrm{D}$; and no history of systemic disease, glaucoma, retinopathy, retinal therapy, or intraocular surgical intervention. Inclusion criteria for the control group were: nonpregnant women; visual acuity $0.00 \log$ MAR without correction; and no history of systemic disease, glaucoma, retinopathy, retinal therapy, or intraocular surgical intervention. Patients who had diabetes mellitus, uveitis, retinopathy, amblyopia, or visual acuity without correction less than $0.00 \log \mathrm{MAR}$, and were younger than 19 years or older than 45 years were excluded.

Foveal thickness at $1 \mathrm{~mm}$, parafoveal thickness at $3 \mathrm{~mm}$ diameter, and RNFL (peripapillary area) were measured by OCT (RTVue-100, Optovue Inc, Fremont, CA) after mydriasis with tropicamide (Alcon, Inc, Fort Worth, TX) drops $1 \%$. Three measurements were taken from the retina for each eye. The average of three measurements was used in the study. The $6 \mathrm{~mm}$ macular map was used to evaluate foveal and parafoveal thickness.

Parafoveal thickness was recorded for upper, temporal, inferior, and nasal quadrants. Findings were analyzed with

Table I Age characteristics

\begin{tabular}{llll}
\hline Group & $\begin{array}{l}\text { Mean age } \\
\text { (years) }\end{array}$ & $\begin{array}{l}\text { Standard } \\
\text { deviation }\end{array}$ & $P$ value \\
\hline $\begin{array}{l}\text { Study group } \\
(\mathrm{n}=40 \text { pregnant women, }\end{array}$ & 28.56 & 4.85 & \\
80 eyes) & & & \\
$\begin{array}{l}\text { Control group } \\
\text { ( } \mathrm{n}=37 \text { nonpregnant women, }\end{array}$ & 27.37 & 4.50 & 0.27 \\
74 eyes) & & & \\
\hline
\end{tabular}

Note: $P$ value $<0.05$ is considered statistically significant.
Table 2 Mean systolic blood pressure

\begin{tabular}{|c|c|c|c|}
\hline \multirow[t]{2}{*}{ Group } & \multicolumn{3}{|c|}{$\begin{array}{l}\text { Mean systolic blood pressure } \\
(\mathrm{mmHg})\end{array}$} \\
\hline & Mean & $\begin{array}{l}\text { Standard } \\
\text { deviation }\end{array}$ & $P$ value \\
\hline $\begin{array}{l}\text { Study group } \\
\text { ( } n=40 \text { pregnant women, } \\
80 \text { eyes) }\end{array}$ & 98.2 & 10.1 & \\
\hline $\begin{array}{l}\text { Control group } \\
\text { ( } n=37 \text { nonpregnant women, } \\
74 \text { eyes) }\end{array}$ & 100.1 & 9.3 & 0.23 \\
\hline
\end{tabular}

statistical software NCSS 2007 and PASS 2008 (NCSS, Kaysville, UT). The study evaluated data with descriptive statistical methods (mean, standard deviation) as well as quantitative parameters showing normal distribution comparisons between the two groups using Student's $t$-test. In all statistical analyses, a $P$ value $<0.05$ was considered statistically significant.

\section{Results}

The study group included 80 eyes of 40 healthy pregnant women (mean age $28.56 \pm 4.85$ years) and the control group included 74 eyes of 37 healthy nonpregnant women (mean age $27.37 \pm 4.5$ years). There was no statistical difference between the two groups in mean age, RNFL, and systolic and diastolic blood pressure (Tables 1-3). The mean visual acuity was $0.00 \log$ MAR in both groups. Mean intraocular pressure was $16.9 \pm 2.9 \mathrm{mmHg}$ in the study group and $19.4 \pm 2.8 \mathrm{mmHg}$ in the control group $(P<0.001$; Table 4).

Mean foveal and parafoveal thicknesses in the study group were: foveal $236.12 \pm 27.28 \mu \mathrm{m}$, upper quadrant $321.31 \pm 12.28 \mu \mathrm{m}$, temporal quadrant $307.0 \pm 12.05 \mu \mathrm{m}$, inferior quadrant $317.0 \pm 10.58 \mu \mathrm{m}$, and nasal quadrant $313.62 \pm 14.51 \mu \mathrm{m}$. Mean foveal and parafoveal thicknesses in the control group were: foveal $224.62 \pm 21.19 \mu \mathrm{m}$,

Table 3 Mean diastolic blood pressure

\begin{tabular}{llll}
\hline Group & \multicolumn{2}{l}{$\begin{array}{l}\text { Mean diastolic blood pressure } \\
(\mathbf{m m H})\end{array}$} \\
\cline { 2 - 4 } & $\begin{array}{l}\text { Mean } \\
\text { Standard } \\
\text { deviation }\end{array}$ & P value \\
\hline $\begin{array}{l}\text { Study group } \\
(\mathrm{n}=40 \text { pregnant women, }\end{array}$ & 58.5 & 10.1 & \\
80 eyes $)$ & & 0.33 \\
$\begin{array}{l}\text { Control group } \\
(\mathrm{n}=37 \text { nonpregnant women, }\end{array}$ & 60.1 & 10.3 & \\
74 eyes $)$ & & \\
\hline Note: $P$ value $<0.05$ is considered statistically significant.
\end{tabular}


Table 4 Mean intraocular pressure

\begin{tabular}{llll}
\hline Group & $\begin{array}{l}\text { Mean intraocular } \\
\text { pressure }(\mathbf{m m H g})\end{array}$ & $\begin{array}{l}\text { Standard } \\
\text { deviation }\end{array}$ & P value \\
\hline $\begin{array}{l}\text { Study group } \\
(\mathrm{n}=40 \text { pregnant }\end{array}$ & 16.9 & 2.9 & \\
$\begin{array}{l}\text { women, } 80 \text { eyes }) \\
\begin{array}{l}\text { Control group } \\
\text { ( } \mathrm{n}=37 \text { nonpregnant }\end{array}\end{array}$ & 19.4 & 2.8 & $<0.00 \mathrm{I}$ \\
women, 74 eyes) & & & \\
\hline
\end{tabular}

Note: $P$ value $<0.05$ is considered statistically significant.

upper quadrant $311.62 \pm 12.71 \mu \mathrm{m}$, temporal quadrant $296.87 \pm 13.78 \mu \mathrm{m}$, inferior quadrant $305.43 \pm 13.25 \mu \mathrm{m}$, and nasal quadrant $304.93 \pm 13.44 \mu \mathrm{m}$. Mean RNFL thickness was similar in both groups (Table 5).

\section{Discussion}

The effects of pregnancy on the eye fall into three categories: (1) in general, healthy pregnant women accumulate 4-6 L fluid in the intra- and extracellular areas over the course of their pregnancy; (2) physiologic changes in pressure, corneal sensitivity, increased corneal thickness, and in visual function can occur; (3) pathologic conditions reported to develop central serous chorioretinopathy, hypertensive and vascular disorders, and uveal melanoma. Pregnancy also can affect preexisting ocular conditions such as diabetic retinopathy, tumors, and immunological disorders. ${ }^{6}$

OCT has been used for retinal examinations in pregnancy in many studies. The macula is especially affected by pregnancy even when healthy - for example, two studies reported infrequent central serous chorioretinopathy in the third trimester in healthy pregnant women. ${ }^{7,8}$ Complications of pregnancy, especially preeclampsia, can lead to loss of vision but these often subside postpartum..$^{9,10}$

During pregnancy and immediately after delivery, OCT may provide information reflecting the relationship between the retina, subretinal space, and retinal pigment epithelium $;{ }^{11}$ it also used for distinguishing retinal edema from serous neurosensory detachment. ${ }^{12}$ OCT has been used in diagnosis of serous neuroretinal detachments, ${ }^{11,13}$ to inspect RNFL in children whose mother smoked during pregnancy, ${ }^{14}$ to measure retinal thickness in the offspring of diabetic pregnancies, ${ }^{15}$ and in follow-up of therapy. ${ }^{16}$ Detection and follow-up of diffuse intraretinal edema in preeclampsia was performed by OCT. ${ }^{17}$ One study showed that mean threshold retinal sensitivity increased significantly in the third trimester. However, it decreased in the upper and lower temporal quadrant. ${ }^{16,18}$

Pregnancy also affects retinal sensitivity, ${ }^{18}$ capillary blood flow, ${ }^{19,20}$ and intraocular pressure. This study showed that the mean intraocular pressure was lower in pregnant women, which is consistent with the literature. ${ }^{21,22}$

\section{Conclusion}

In this study, participants with glaucoma were excluded with measurement of intraocular pressure, visual field tests, and optic disc examination and foveal, parafoveal, and RNFL thickness in healthy pregnant women in their last trimester were compared with a control group. Mean RNFL thickness was similar in both groups. Means of all measurements in foveal and parafoveal thickness were higher in pregnant women than a control group. However, the statistically significant difference in thickness was only found in upper, temporal, and inferior parafoveal areas.

Fluid volume in the body increases during pregnancy secondary to hormonal changes, for example corneal thickness increases during pregnancy. However, the increase of retinal thickness may be secondary to the increase and accumulation of intraretinal or intraretinal cellular fluid.

Further studies with a larger number of patients are required to confirm this difference. The main limitation of this study is the small number of cases.

Table 5 Mean foveal, parafoveal, and retinal nerve fiber layer (RNFL) thicknesses

\begin{tabular}{|c|c|c|c|}
\hline & $\begin{array}{l}\text { Study group ( } n=40 \\
\text { pregnant women, } 80 \text { eyes) }\end{array}$ & $\begin{array}{l}\text { Control group ( } n=37 \\
\text { nonpregnant women, } 74 \text { eyes) }\end{array}$ & $P$ value \\
\hline & Mean \pm standard deviation & Mean \pm standard deviation & \\
\hline Foveal $(\mu \mathrm{m})$ & $236.12 \pm 27.28$ & $224.62 \pm 21.19$ & 0.193 \\
\hline Upper quadrant $(\mu \mathrm{m})$ & $321.31 \pm 12.28$ & $311.62 \pm 12.71$ & 0.036 \\
\hline Temporal quadrant $(\mu \mathrm{m})$ & $307.0 \pm 12.05$ & $296.87 \pm 13.78$ & 0.035 \\
\hline Inferior quadrant $(\mu \mathrm{m})$ & $317.0 \pm 10.58$ & $305.43 \pm 13.25$ & 0.011 \\
\hline Nasal quadrant $(\mu \mathrm{m})$ & $313.62 \pm|4.5|$ & $304.93 \pm 13.44$ & 0.089 \\
\hline RNFL ( $\mu \mathrm{m})$ & $108.12 \pm 13.1$ & $110.05 \pm 12.4$ & 0.481 \\
\hline
\end{tabular}

Note: $P$ value $<0.05$ is considered statistically significant. 


\section{Disclosure}

The authors report no conflicts of interest in this work.

\section{References}

1. Kubica-Trazaska A, Karska-Basta I, Kobylarz J, Romanowska-Dixon B. Pregnancy and the eye. Klin Oczna. 2008;110(10-12):401-404. Polish.

2. Sheth BP, Mieler WF. Ocular complications of pregnancy. Curr Opin Ophthalmol. 2001;12(6):455-463.

3. Omoti AE, Waziri-Erameh JM, Okeigbemen VW. A review of the ophthalmic and visual system in pregnancy. Afr $J$ Reprod Health. 2008;12(3):185-196.

4. Stalnikiewicz L, Floriot M, Guerci B, Anqioi K. Progression of diabetic retinopathy during pregnancy: a retrospective analysis of a series of 77 consecutive patients. J Fr Ophtalmol. 2010;33(7):481-486.

5. Vestgaard M, Ringholm L, Laugesen CS, Rasmussen KL, Damm P, Mathiesen ER. Pregnancy-induced sight-threatening diabetic retinopathy in women with type 1 diabetes. Diabet Med. 2010;27(4):431-435.

6. Sunness JS. The pregnant woman's eye. Surv Ophthalmol. 1988;32(4): 219-238.

7. Gass JD. Central serous chorioretinopathy and white subretinal exudation during pregnancy. Arch Ophthalmol. 1991;109(5):677-681.

8. Fastenberg DM, Ober RR. Central serous chorioretinopathy in pregnancy. Arch Ophthalmol. 1983;101(7):1055-1058.

9. Ehlers JP, Maguire JI. Bilateral visual loss reveals occult pregnancy. Ophthalmic Surg Lasers Imaging. 2008;39(2):150-152.

10. Dinn RB, Harris A, Marcus PS. Ocular changes in pregnancy. Obstet Gynecol Surv. 2003;58(2):137-144.

11. Rezai KA, Eliott D. Optical coherence tomographic findings in pregnancy-associated central serous chorioretinopathy. Graefes Arch Clin Exp Ophthalmol. 2004;242(12):1014-1016.
12. Schultz KL, Birnbaum AD, Goldstein DA. Ocular disease in pregnancy. Curr Opin Ophthalmol. 2005;16(5):308-314.

13. Somfai GM, Mihaltz K, Tulassay E, Rigo J Jr. Diagnosis of serous neuroretinal detachments of the macula in severe preeclamptic patients with optical coherence tomography. Hypertens Pregnancy. 2006;25(1): $11-20$.

14. Pueyo V, Güerri N, Oros D, et al. Effects of smoking during pregnancy on the optic neurodevelopment. Early Hum Dev. 2011;87(5):331-334.

15. Tariq YM, Samarawickrama C, Li H, Huynh SC, Burlutsky G, Mitchell P. Retinal thickness in the offspring of diabetic pregnancies. Am J Ophthalmol. 2010;150(6):883-887.

16. Tarantola RM, Folk JC, Boldt HC, Mahajan VB. Intravitreal bevacizumab during pregnancy. Retina. 2010;30(9):1405-1411.

17. Theodossiadis PG, Kollia AK, Gogas P, Panagiotidis D, Moschos M, Theodossiadis GP. Retinal disorders in preeclampsia studied with optical coherence tomography. Am J Ophthalmol. 2002;133(5):707-709.

18. Akar Y, Yucel I, Akar ME, Uner M, Trak B. Long-term fluctuation of retinal sensitivity during pregnancy. Can J Ophthalmol. 2005;40(4): 487-491.

19. Loukovaara S, Harju M, Kaaja R, Immonen I. Retinal capillary blood flow in diabetic and nondiabetic women during pregnancy and postpartum period. Invest Ophthalmol Vis Sci. 2003;44(4):1486-1491.

20. Loukovaara S, Kaaja R, Immonen I. Macular capillary blood flow velocity blue-field entoptoscopy in diabetic and healthy women during pregnancy and the postpartum period. Graefes Arch Clin Exp Ophthalmol. 2002;240(12):977-982.

21. Akar Y, Yucel I, Akar ME, Zorlu G, Ari ES. Effect of pregnancy on intraobserver and intertechnique agreement in intraocular pressure measurements. Ophthalmologica. 2005;219(1):36-42.

22. Qureshi IA, Xi XR, Yagob T. The ocular hypotensive effect of late pregnancy is higher in multigravidae than in primigravidae. Graefes Arch Clin Exp Ophthalmol. 2000;238(1):64-67.
Clinical Ophthalmology

\section{Publish your work in this journal}

Clinical Ophthalmology is an international, peer-reviewed journal covering all subspecialties within ophthalmology. Key topics include: Optometry; Visual science; Pharmacology and drug therapy in eye diseases; Basic Sciences; Primary and Secondary eye care; Patient Safety and Quality of Care Improvements. This journal is indexed on Submit your manuscript here: http://www.dovepress.com/clinical-ophthalmology-journal

\section{Dovepress}

PubMed Central and CAS, and is the official journal of The Society of Clinical Ophthalmology (SCO). The manuscript management system is completely online and includes a very quick and fair peer-review system, which is all easy to use. Visit http://www.dovepress.com/ testimonials.php to read real quotes from published authors. 